\title{
Wines produced with 'Cabernet Sauvignon' grapes from the region of Bagé in the state of Rio Grande do Sul, Brazil
}

\author{
Renata Gimenez Sampaio Zocche ${ }^{(1)}$, Suziane Antes Jacobs(1), Norton Victor Sampaio(1), Velci Queiróz de Souza(1), \\ Ivan Ricardo Carvalho ${ }^{(2)}$, Maicon Nardino(2), Luiz Antenor Rizzon ${ }^{(3)}$ and Cesar Valmor Rombaldi(2) \\ (1)Universidade Federal do Pampa, Rua 21 de Abril, no 80, CEP 96450-000 Dom Pedrito, RS, Brazil. E-mail: rehaesbaert@hotmail.com, \\ suzi.antes@hotmail.com, nortonsampaio@unipampa.edu.br, velciq@gmail.com ${ }^{(2)}$ Universidade Federal de Pelotas, Campus Universitário, \\ s/no, CEP 96010-610 Capão do Leão, RS, Brazil. E-mail: carvalho.irc@gmail.com,nardinomn@gmail.com, cesarvrf@ufpel.edu.br \\ (3)Embrapa Uva e Vinho, Rua Livramento, o 515, Caixa Postal 130, CEP 95701-008 Bento Gonçalves, RS, Brazil. E-mail: \\ rizzon@cnpuv.embrapa.br
}

\begin{abstract}
The objective of this work was to characterize 'Cabernet Sauvignon' wines made from grapes cultivated in the region of Bagé, RS, Brazil, during three crop seasons. A randomized complete block design was carried out with three treatments and three replicates. The evaluations were performed for the 2004, 2007, and 2008 growing seasons. 'Cabernet Sauvignon' wines of the 2004, 2008, and 2009 harvests differed for the following parameters: density, alcoholic content, total acidity, $\mathrm{pH}$, reducing sugars, OD 420, 520, and 620 , color intensity, total anthocyanins, total polyphenols, sodium, calcium, magnesium, manganese, copper, iron, rubidium, phosphorus, methanol, propanol, 2-methyl-1-propanol, 2, 3 - methyl-1-butanol, and sum of alcohols. 'Cabernet Sauvignon' has potential to be produced in the Bagé region, and to help it to become a wine growing region in Brazil.
\end{abstract}

Index terms: color stability, enology, grape production, physicochemical characters, potassium.

\section{Vinhos produzidos com a uva 'Cabernet Sauvignon' da região de Bagé, no Rio Grande do Sul}

\begin{abstract}
Resumo - O objetivo deste trabalho foi caracterizar vinhos 'Cabernet Sauvignon' elaborados com uvas produzidas na região de Bagé, RS, durante três safras. Um delineamento experimental de blocos ao acaso foi realizado com três tratamentos e três repetições. As avaliações foram feitas para as safras de 2004, 2007 e 2008. Os vinhos 'Cabernet Sauvignon' das safras 2004, 2008 e 2009 diferiram quanto aos seguintes parâmetros: densidade, teor alcoólico, acidez total, $\mathrm{pH}$, açúcares redutores, DO 420, 520 e 620, intensidade de cor, antocianinas totais, polifenóis totais, sódio, cálcio, magnésio, manganês, cobre, ferro, rubídio, fósforo, metanol, propanol, 2-methyl-1-propanol, 2,3 - methyl-1-butanol e soma de álcoois. 'Cabernet Sauvignon' tem potencial de ser produzida na região de Bagé e contribuir para que ela venha a se tornar um polo vinícola no Brasil.
\end{abstract}

Termos para indexação: estabilidade de cor, enologia, viticultura, características físico-químicas, potássio.

\section{Introduction}

'Cabernet Sauvignon' wine, either of varietal or assemblage origin (Jacobs et al., 2016), stands out among winegrowers. The range of cultivars from the genus Vitis vinifera (Zocche et al., 2016) allows the production and appreciation of these wines under Brazilian and worldwide conditions (Jayaprakasha et al., 2001). This genotype is from the Bordeaux region of France and, phenologically, its plants have late sprouting and maturity, with medium vigor and productivity (Rizzon \& Miele, 2002). It is hevely dependent on edaphoclimatic conditions, and on the technology and management strategies used by winegrowers (Bail et al., 2008). Research carried out by Jackson (2008) showed that this genotype is the best known and most studied in Europe because it provides wines of superior potential and intense aromas, similar to blackcurrants, when produced under favorable edaphoclimatic conditions. However, 
it has an herbaceous aroma when the environmental conditions are adverse (Falcão et al., 2008).

The terroir is intrinsic to the edaphoclimatic conditions of the growing environment - such as air and soil temperature, relative air humidity, photosynthetically active radiation, thermal amplitude, altitude, latitude, soil type, water and nutritional availability, and some biotic events inherent to the environment, where the same genotype tends to modify the characteristics of the produced wine (Fischer et al., 1999; Rizzon \& Miele, 2002, 2003, 2004; González-Neves et al., 2004; Cosme et al., 2009; Parr et al., 2009; Tao et al., 2009). Crop management aspects of 'Cabernet Sauvignon' in Serra Gaúcha and Santana do Livramento regions influence the acidity and quality of the produced wine (Manfroi et al., 1997; Rizzon et al., 1998). Low temperatures affected grape pre-fermentation in the municipality of Dom Pedrito, in the state of Rio Grande do Sul (Pötter et al., 2010).

Studies on this genotype show its acclimatization and adaptation to the specific conditions of each growing environment, evidencing the conditions to which the genotype is subjected; therefore, changes regarding phenolic maturation were perceptible (Bertagnolli et al., 2007), as the wines showed a pronounced astringency, the presence of pyrazines, and a flavour considered herbaceous by sensory perception (Rizzon $\&$ Miele, 2002; Pötter et al., 2010).

Although the region of Bagé has already produced and marketed 'Cabernet Sauvignon' grapes for more than ten years, studies reporting its oenological potential are still scarce.

The objective of this work was to characterize 'Cabernet Sauvignon' wines made from grapes grown in the region of Bagé, RS, Brazil, during three crop seasons $(2004,2007$, and 2008), considering that this region has potential to be a wine producing center in the country.

\section{Materials and Methods}

The study was carried out in a vineyard established in 2000, with vines of the 'Cabernet Sauvignon' genotype, clone CS18A, grafted on 'Paulsen 1103', conducted in a single espalier, with $1.2 \mathrm{~m}$ spacing between plants, and $3.0 \mathrm{~m}$ between rows. The vines were pruned using a double spore cord, and the height of the canopy was approximately $1.20 \mathrm{~m}$. For this study, grapes were collected from the same vineyard, located in Olhos D'Água, in the region of Bagé, in the Campanha Gaúcha (at 31 $19^{\prime} 53^{\prime \prime} \mathrm{S}, 54^{\circ} 06^{\prime} 25^{\prime \prime} \mathrm{W}$ ).

A randomized block design was carried out with three treatments and three replicates. Considered as treatments, the harvests of 2004, 2007, and 2008 were evaluated. The harvest stage and processes followed the common procedures for industrial purposes, with grapes between 20.1 and $21.1^{\circ}$ Brix, 87 and 93 meq $\mathrm{L}^{-1}$ of titratable acidity (TA), $\mathrm{pH}$ between 3.43 and 3.59, and density between 1.0852 and $1.0901 \mathrm{~g} \mathrm{~cm}^{-3}$, seed with a light brown color, and average yield for the three harvests of $2.5 \mathrm{~kg}$ of grapes per plant. The soil is characterized as a Planossolo Vértico (Santos et al., 2013) - Vertic Planosol. Soil analysis was performed at $0.40 \mathrm{~m}$ soil depth, whose samples showed $\mathrm{pH} 5.0$ and $240 \mathrm{~g} \mathrm{~kg}^{-1}$ clay content, $12 \mathrm{~g} \mathrm{~kg}^{-1}$ organic matter, $3.5 \mathrm{mg}$ $\mathrm{dm}^{-3} \mathrm{P}$, and $80 \mathrm{mg} \mathrm{dm}^{-3} \mathrm{~K}$. The control of weeds, pest insects, and diseases was carried out according to the crop demand, allowing plants to be free from biotic stresses, thus, minimizing the environment influences on the experiment result (Zocche et al., 2016).

For this experiment, three microvinification processes were carried out in each harvest, which was considered as experimental unit, in order to carry out the statistical analyses. The experimental unit consisted of $20 \mathrm{~L}$ bottles, in which $17 \mathrm{~kg}$ of grapes were peeled off and crushed and, immediately after, $50 \mathrm{mg} \mathrm{L} \mathrm{SO}$ and $20 \mathrm{mg} \mathrm{L}$ of Saccharomyces cereviseae yeasts (Maurivin, AB Mauri, Camellia, NSW, Australia) were added. Maceration was carried out for six days at 20 to $25^{\circ} \mathrm{C}$, with daily repression, and cap removal on the seventh day after the beginning of the process.

As soon as alcoholic fermentation finished, racking was performed, and the malolactic fermentation was monitored, which lasted, on average, four months. After that, the tartaric stabilization was performed in a cold chamber at $4^{\circ} \mathrm{C}$ for ten days, and the wines were bottled. Physicochemical evaluations were performed eight months after the beginning of winemaking (Jacobs et al., 2016; Zocche et al., 2016). The evaluated characters were: density, alcoholic content, total and volatile acidity, $\mathrm{pH}$, reducing sugars (Amerine \& Ough, 1976), total polyphenols, anthocyanins, and color intensity (Ribéreau-Gayon \& Stonestreet, 1965). The contents of $\mathrm{Ca}, \mathrm{Mg}, \mathrm{Mn}, \mathrm{Fe}, \mathrm{Cu}$ and $\mathrm{Zn}$ were obtained by atomic absorption analyses, whereas $\mathrm{K}, \mathrm{Na}, \mathrm{Li}$, and $\mathrm{Rb}$ contents were obtained by flame 
emission (Analytical..., 1976). Phosphorus content was determined by calorimetry using ammonium molybdate. The volatile compounds ethyl acetate, methanol, propanol-1, 2-methyl-1-propanol, 2,3 methyl-1-butanol, and the sum of the higher alcohols were determined by gas chromatography, in an apparatus equipped with a flame ionization detector, and a Carbowax 600 stainless steel column of $3.2 \mathrm{~m}$ long and " $1 / 8$ " internal diameter. The gas vector used was nitrogen with $30 \mathrm{~mL} \mathrm{~min}^{-1}$ flow of. The vaporizer was at $140^{\circ} \mathrm{C}$, oven temperature was $98^{\circ} \mathrm{C}$, and the detector was at $160^{\circ} \mathrm{C}$. The wine sample $(3 \mu \mathrm{L})$ was directly injected after receiving $10 \%$ volume of a solution of methyl-4-pentanol-2 at $1 \mathrm{~g} \mathrm{~L}^{-1}$ as an internal standard (Bertrand, 1975).

The sensorial analysis was conducted after six months of wine bottling, by a panel of 11 trained wine tasters who legally committed to the research participation being aware of the ethical and scientific responsibility of the research. They have the ability to quantify the aromatic, gustatory, and visual descriptors in red wines. The evaluations were performed for three consecutive days, where each taster was considered as the experimental unit of each treatment, and the magnitude of evaluation comprised scores from zero to nine according to the perceived intensity. The used descriptors were: color intensity, purplish red intensity, aromatic intensity, red fruit, dried fruit, tobacco/ chocolate/tea, vegetable/herbaceous, volume of mouth, tannic sweetness, acidity, astringency, persistence, and overall evaluation.

Data were subjected to the normality test of Shapiro $\&$ Wilk (1965). The analysis of variance was performed at $5 \%$ probability, and the significant characters were analyzed by Tukey's test. The analyses were performed using the Genes statistical software (Cruz, 2013).

\section{Results and Discussion}

The analysis of variance showed significant differences between the 2004, 2007, and 2008 growing seasons for density, alcohol content, total acidity, $\mathrm{pH}$, total sugars, L420, L520, L620, color intensity, polyphenols, anthocyanins, $\mathrm{Na}, \mathrm{Ca}, \mathrm{Mg}, \mathrm{Mn}, \mathrm{Cu}, \mathrm{Fe}$, $\mathrm{Rb}$, $\mathrm{P}$, ethyl acetate, methanol, propanol-1, 2-methyl1-propanol, 2,3 - methyl-1-butanol, and sum of the higher alcohols. However, no differences were found for volatile acidity, dry extract, tannins, $\mathrm{K}, \mathrm{Zn}$, and acetaldehyde, which regardless of the harvest, tend to respond in a similar way in the conditions of Bagé region (Table 1).

The wine density was higher for harvests of 2004 and 2007 than that of 2008 (Table 2). These results agree with a study about wine production in Rio Grande do Sul (Rizzon \& Miele, 2002).

Alcohol content was higher in the 2004 harvest. However, for all harvests, the contents were above $10.5 \%$. The content of soluble solids of Bagé region allows of wine production with the minimum alcoholic content required by the national laws $\left(\geq 7^{\circ} \mathrm{GL}\right)$, without

Table 1. Summary of the variance analysis of the evaluated characters.

\begin{tabular}{|c|c|c|}
\hline Character & $\begin{array}{c}\text { Mean squares } \\
\text { Harvests }\end{array}$ & $\begin{array}{l}\text { Coeficient of } \\
\text { variation (\%) }\end{array}$ \\
\hline Density $\left(20 / 20^{\circ} \mathrm{C}\right)$ & $0.0001^{*}$ & 0.05 \\
\hline Alcoholic content $(\% \mathrm{v} / \mathrm{v})$ & $1.4222 *$ & 3.21 \\
\hline Total acidity (meq $\mathrm{L}^{-1}$ ) & $272.3333 *$ & 0.94 \\
\hline Volatile acidity (meq $\left.\mathrm{L}^{-1}\right)$ & $1.0278^{\mathrm{ns}}$ & 11.52 \\
\hline $\mathrm{pH}$ & $0.0525^{*}$ & 1.92 \\
\hline Reducing sugars $\left(\mathrm{g} \mathrm{L}^{-1}\right)$ & $2.0053^{*}$ & 3.50 \\
\hline Dry extract & $15.2659^{\mathrm{ns}}$ & 6.17 \\
\hline OD 420 & $0.0688^{*}$ & 12.33 \\
\hline OD 520 & $0.0279 *$ & 19.08 \\
\hline OD 620 & $0.0094 *$ & 16.72 \\
\hline $\begin{array}{l}\text { Color intensity (OD } 420+ \\
\text { OD } 520+\text { OD } 620)\end{array}$ & $0.2680^{*}$ & 15.85 \\
\hline Tannins & $0.0262^{\text {ns }}$ & 5.32 \\
\hline Total anthocyanins $\left(\mathrm{mg} \mathrm{L}^{-1}\right)$ & $131495.8107 *$ & 8.87 \\
\hline Total polyphenols $\left(\mathrm{mg} \mathrm{L}^{-1}\right)$ & $7.6369^{*}$ & 0.92 \\
\hline Acetaldehyde & $167.4071^{\mathrm{ns}}$ & 58.56 \\
\hline Ethyl acetate & $539.6125^{*}$ & 12.09 \\
\hline Methanol & $28807.8025^{*}$ & 16.71 \\
\hline Propanol & $196.0715^{*}$ & 13.55 \\
\hline 2-methyl-1-propanol & $13921.4737^{*}$ & 8.71 \\
\hline 2.3-methyl-1-butanol & $185022.2195^{*}$ & 7.60 \\
\hline Sum of higher alcohols & $29541.7344^{*}$ & 8.09 \\
\hline $\mathrm{K}$ & $51582.9514^{\mathrm{ns}}$ & 7.87 \\
\hline $\mathrm{Na}$ & $50.0200^{*}$ & 13.42 \\
\hline $\mathrm{Ca}$ & $363.6487^{*}$ & 4.77 \\
\hline $\mathrm{Mg}$ & $299.8685^{*}$ & 2.77 \\
\hline $\mathrm{Mn}$ & $6.9922 *$ & 2.21 \\
\hline $\mathrm{Cu}$ & $2.6924 *$ & 10.28 \\
\hline $\mathrm{Fe}$ & $1.4366^{*}$ & 5.11 \\
\hline $\mathrm{Zn}$ & $0.0084^{\mathrm{ns}}$ & 23.62 \\
\hline $\mathrm{Rb}$ & $11.0461 *$ & 18.17 \\
\hline $\mathrm{P}$ & $2203.0905^{*}$ & 3.25 \\
\hline
\end{tabular}

*Significant at $5 \%$ probability. ${ }^{\mathrm{n}}$ Nonsignificant. OD, optical density.

Pesq. agropec. bras., Brasília, v.52, n.5, p.311-318, maio 2017 DOI: $10.1590 / \mathrm{S} 0100-204 \mathrm{X} 2017000500004$ 
the need of must concentration or chaptalization (Zocche et al., 2016). Total acidity of the harvests responded differently, and this character was higher in the 2004 harvest; however, the wines showed relatively low values, between 51 and $69 \mathrm{meq} \mathrm{L}^{-1}$, and $\mathrm{pH}$ values were close to 4.0 .

The volatile acidity and dry extracts did not differ between harvests (Table 2). Relatively low values of total acidity and high $\mathrm{pH}$ values result in wines with stability problems during maturation, especially those related to color components, such as anthocyanins and their interactions with tannins (Jacobs et al., 2016). Singleton (1987) found that the oxidation rate of wines with $\mathrm{pH} 4.0$ is nine times higher than wines with $\mathrm{pH}$ 3.0. The total acidity in the 2004 harvest was lower than the minimum limit stipulated by the Brazilian laws (55 meq $\mathrm{L}^{-1}$ ), and a $\mathrm{pH}$ of 4,185 was obtained. In the subsequent growing seasons (2007 and 2008), the values were very close, but were higher than the 2004 harvest; thus, the characters indicating coloration (Table 3) showed, for two harvests, higher levels than that of 2004 for OD 420, 520, and 620, color intensity, anthocyanins, polyphenols, and a shade brick color.

Although 'Cabernet Sauvignon' is not one of the richest grapes in anthocyanins, in comparison with grapes such as 'Alicante Bouchet' or 'Tannat', in several wine regions near the study area it was able to produce wines with good coloration (Pötter et al., 2010; Jacobs et al., 2016). Complementary oenological practices are usually associated with the use of pectolytic enzymes, thermovinification, the use of modular temperatures, fermentative pre-maceration at low temperatures (Zocche et al., 2016), correction of acidity, the use of oenological tannins, micro-oxygenation, other resources in the search for greater extraction of color and structure components, and stabilization during wine maturation process (Fernández-Zurbano et al., 1999; Carvalho \& Curvelo-Garcia, 2000; Pérez-Lamela et al., 2007; Daudt \& Fogaça, 2008; Chinnici et al., 2009; Pötter et al., 2010).

When evaluating wines produced with 'Cabernet Sauvignon' grapes in Bagé region, it was evidenced that, without using complementary oenological processes, the obtained product is unsatisfactory as for coloration and total polyphenol concentrations (Jacobs et al., 2016). The values observed in these wines were lower than those obtained in a research carried out in Rio Grande do Sul (Rizzon \& Miele, 2002). According to González-Neves et al. (2004), the year of 2007 showed a wetter period during grape maturation, and even producing grapes with good content of soluble solids (above $20^{\circ}$ Brix), the color characteristics were lower.

As to the wine mineral composition, the 2008 harvest showed a higher concentration of sodium, magnesium, and rubidium. However, calcium showed a greater magnitude in 2007, and manganese, copper,

Table 2. Physicochemical composition of 'Cabernet Sauvignon' wines produced with grapes from the region of Bagé, RS, Brazil, in the 2004, 2007, and 2008 growing seasons ${ }^{(1)}$.

\begin{tabular}{|c|c|c|c|c|c|c|c|}
\hline Harvest & $\begin{array}{c}\text { Density } \\
\left(20 / 20^{\circ} \mathrm{C}\right) \\
\end{array}$ & $\begin{array}{c}\text { Alcoholic content } \\
(\% \mathrm{v} / \mathrm{v})\end{array}$ & $\begin{array}{c}\text { Total acidity } \\
\left(\text { meq L } \mathrm{L}^{-1}\right)\end{array}$ & $\begin{array}{c}\text { Volatile acidity } \\
\left(\text { meq L }^{-1}\right)\end{array}$ & $\mathrm{pH}$ & $\begin{array}{c}\text { Reducing sugars } \\
\left(\mathrm{g} \mathrm{L}^{-1}\right)\end{array}$ & Dry extract \\
\hline 2004 & $0.996 \mathrm{a}$ & $11.926 a$ & $51.000 \mathrm{c}$ & $7.500 \mathrm{a}$ & $4.185 \mathrm{a}$ & $1.325 \mathrm{c}$ & $22.940 \mathrm{a}$ \\
\hline 2007 & $0.995 \mathrm{a}$ & $10.833 b$ & $69.333 a$ & $8.000 \mathrm{a}$ & $3.926 b$ & $2.960 \mathrm{a}$ & $27.360 \mathrm{a}$ \\
\hline 2008 & $0.985 b$ & $10.655 \mathrm{~b}$ & $64.666 \mathrm{~b}$ & $8.666 \mathrm{a}$ & $4.006 \mathrm{ab}$ & $2.123 b$ & $24.367 \mathrm{a}$ \\
\hline
\end{tabular}

${ }^{(1)}$ Means followed by equal letters, lowercase in the columns, do not differ by the Tukey's test, at $5 \%$ probability.

Table 3. Means of physicochemical composition of 'Cabernet Sauvignon' wines produced with grapes from the region of Bagé, RS, Brazil, in the 2004, 2007, and 2008 growing seasons ${ }^{(1)}$.

\begin{tabular}{|c|c|c|c|c|c|c|c|}
\hline Harvest & OD 420 & OD 520 & OD 620 & Color intensity & Tannins & $\begin{array}{l}\text { Total anthocyanins } \\
\left(\mathrm{mg} \mathrm{L}^{-1}\right)\end{array}$ & $\begin{array}{l}\text { Total polyphenols } \\
\left(\mathrm{mg} \mathrm{L}^{-1}\right)\end{array}$ \\
\hline 2004 & $0.368 \mathrm{a}$ & $0.384 \mathrm{a}$ & $0.139 \mathrm{a}$ & $0.892 \mathrm{a}$ & $1.530 \mathrm{a}$ & $393.630 \mathrm{a}$ & $36.550 \mathrm{a}$ \\
\hline 2007 & $0.068 \mathrm{c}$ & $0.192 b$ & $0.033 b$ & $0.294 \mathrm{c}$ & $1.688 \mathrm{a}$ & $323.72 b$ & $33.400 \mathrm{c}$ \\
\hline 2008 & $0.253 b$ & $0.306 \mathrm{ab}$ & $0.053 b$ & $0.614 b$ & $1.522 \mathrm{a}$ & $1.140 \mathrm{c}$ & $34.533 a$ \\
\hline
\end{tabular}

${ }^{(1)}$ Means followed by equal letters, lowercase in the columns, do not differ by the Tukey's test, at 5\% probability. OD, optical density. 
iron, and phosphorus were relevant in the 2004 harvest (Table 4). An important aspect to be highlighted is the wine mineral constitution behavior between harvests, with outstanding alterations between grapes of plants of 4 and 8 years. Considering this, the oenological potential improvement of grapes occurs as the age of the vineyard advances and sanitary conditions are enhanced (Rizzon et al., 2008). The excess of K may cause a reduction of total acidity, an increase of $\mathrm{pH}$, anthocyanin destabilizations, and an intensification of purplish and yellowish colors (Daudt \& Fogaça, 2008).

Research by Pötter et al. (2010) with 'Cabernet Sauvignon' grapes, in Dom Pedrito, RS, resulted in wines with $\mathrm{pH}$ below 3.6, but with high total polyphenols and coloration. High $\mathrm{pH}$ values and low total acidity tend to increase $\mathrm{K}$ uptake dynamics, culminating in the excessive precipitation of $\mathrm{K}$ bitartrate during winemaking (Daudt \& Fogaça, 2008). Since studies are scarce to prove this dynamic, attention should be redoubled to the vineyard intrinsic type of soil, as K absorption by 'Cabernet Sauvignon' genotype is modified. In a comparison of wines produced with the same genotype, $\mathrm{K}$ concentrations were different, even under the same climatic indexes in Campanha Gaúcha region (Bagé and Dom Pedrito, RS) (Jacobs et al., 2016).

According to Leeuwen et al. (2004), K contents in grapes depend on the soil type and on the genotype used. In wines produced from grapes cultivated in Bagé, the K contents varied from 1,694 to $1,947 \mathrm{mg} \mathrm{L}^{-1}$. According to Rizzon \& Miele (2002), K levels reached $1,426 \mathrm{mg} \mathrm{L}^{-1}$ in the average of six harvests for 'Cabernet Sauvignon' in the Serra Gaúcha region, also in the state of Rio Grande do Sul, Brazil. Some aspects may affect $\mathrm{K}$ uptake in 'Cabernet Sauvignon' vineyards, in the region of Bagé, such as low relative humidity in the maturation period, great evapotranspiration, mass flow through xylem vessels, and vineyard composed of grafted plants on 'Paulsen' rootstock, which shows an abundant and deep radicular system, with a greater capacity to absorb water and nutrients (Zocche et al., 2016).

As to volatile compounds of the wines, the 2007 and 2008 harvests were superior for methanol and propanol contents, whereas the 2004 harvest showed greater values for 2-methyl-1-propanol, 2,3 - methyl-1butanol, and for the sum of higher alcohols (Table 5). The volatile compounds remained within the normal standards for fine red wines. According to Rizzon \& Miele (2002), the presence of high concentrations of amylic alcohols (2-methyl-1-propanol, 2,3 - methyl-1butanol) is characteristic of wines of this genotype, thus favoring herbaceous aroma often detected in them.

The higher alcohols were especially elevated in the first harvest, reflecting wines with a shortage of

Table 4. Means of mineral composition of 'Cabernet Sauvignon' wines produced with grapes from the region of Bagé, RS, Brazil, in the 2004, 2007, and 2008 growing seasons ${ }^{(1)}$.

\begin{tabular}{lcccccccccc}
\hline Harvest & $\mathrm{K}$ & $\mathrm{Na}$ & $\mathrm{Ca}$ & $\mathrm{Mg}$ & $\mathrm{Mn}$ & $\mathrm{Cu}$ & $\mathrm{Fe}$ & $\mathrm{Zn}$ & $\mathrm{Rb}$ & $\mathrm{P}$ \\
\hline 2004 & $1947.1 \mathrm{a}$ & $12.9 \mathrm{~b}$ & $68.55 \mathrm{~b}$ & $84.90 \mathrm{~b}$ & $5.00 \mathrm{a}$ & $1.50 \mathrm{a}$ & $2.20 \mathrm{a}$ & $0.40 \mathrm{a}$ & $4.20 \mathrm{~b}$ & $166.83 \mathrm{a}$ \\
2007 & $1694.2 \mathrm{a}$ & $10.75 \mathrm{~b}$ & $79.71 \mathrm{a}$ & $87.23 \mathrm{~b}$ & $4.14 \mathrm{~b}$ & $0.22 \mathrm{c}$ & $1.16 \mathrm{~b}$ & $0.29 \mathrm{a}$ & $5.51 \mathrm{ab}$ & $136.15 \mathrm{~b}$ \\
2008 & $1880.8 \mathrm{a}$ & $18.65 \mathrm{a}$ & $57.69 \mathrm{c}$ & $103.26 \mathrm{a}$ & $2.03 \mathrm{c}$ & $0.50 \mathrm{~b}$ & $0.88 \mathrm{c}$ & $0.37 \mathrm{a}$ & $7.97 \mathrm{a}$ & $112.80 \mathrm{c}$ \\
\hline
\end{tabular}

${ }^{(1)}$ Means followed by lowercase letters, in the columns, do not differ by the Tukey's test, at $5 \%$ probability.

Table 5. Means of volatile compounds of 'Cabernet Sauvignon' wines produced with grapes from the region of Bagé, RS, Brazil, in the 2004, 2007, and 2008 growing seasons ${ }^{(1)}$.

\begin{tabular}{lccccccc}
\hline Harvest & Acetaldehyde & Ethyl acetate & Methanol & Propanol & $\begin{array}{c}\text { 2-methyl-1- } \\
\text { propanol }\end{array}$ & $\begin{array}{c}2.3-\text { Methyl-1- } \\
\text { butanol }\end{array}$ & $\begin{array}{c}\text { Sum of higher } \\
\text { alcohols }\end{array}$ \\
\hline 2004 & $8.25 \mathrm{a}$ & $60.15 \mathrm{a}$ & $31.85 \mathrm{~b}$ & $17.90 \mathrm{~b}$ & $132.25 \mathrm{a}$ & $4454.40 \mathrm{a}$ & $604.60 \mathrm{a}$ \\
2007 & $23.16 \mathrm{a}$ & $83.40 \mathrm{a}$ & $219.67 \mathrm{a}$ & $28.20 \mathrm{ab}$ & $42.73 \mathrm{~b}$ & $252.83 \mathrm{~b}$ & $413.07 \mathrm{~b}$ \\
2008 & $16.43 \mathrm{a}$ & $60.19 \mathrm{a}$ & $1744.25 \mathrm{a}$ & $33.84 \mathrm{a}$ & $56.65 \mathrm{~b}$ & $104.544 \mathrm{c}$ & $463.80 \mathrm{~b}$ \\
\hline
\end{tabular}

${ }^{(1)}$ Means followed by lowercase letters, in the columns, do not differ by the Tukey's test, at $5 \%$ probability. 
refined aromas. Methanol and acetaldehyde at low concentrations indicate that the grapes were harvested in a good phytosanitary state, whose vinification process was also well conducted.

According to the sensorial analysis, the wines produced with 'Cabernet Sauvignon' from the 2008 harvest reached average scores below 5 for color intensity, red fruit aromas, volume in the mouth, and persistence; these scores are considered below standards for attributes usually considered as positive for red wine, indicating the low quality of these wines (Figure 1). The panel results agreed with those obtained by the analytical data, and indicate that the wines do not show a good concentration of color and structure components, which reflected in the sensorial evaluation. Therefore, there is a need for complementary studies to characterize the maturation evolution of this genotype in this environment, with practices to elucidate the nutrient absorption dynamics and their mobility to the fruit.

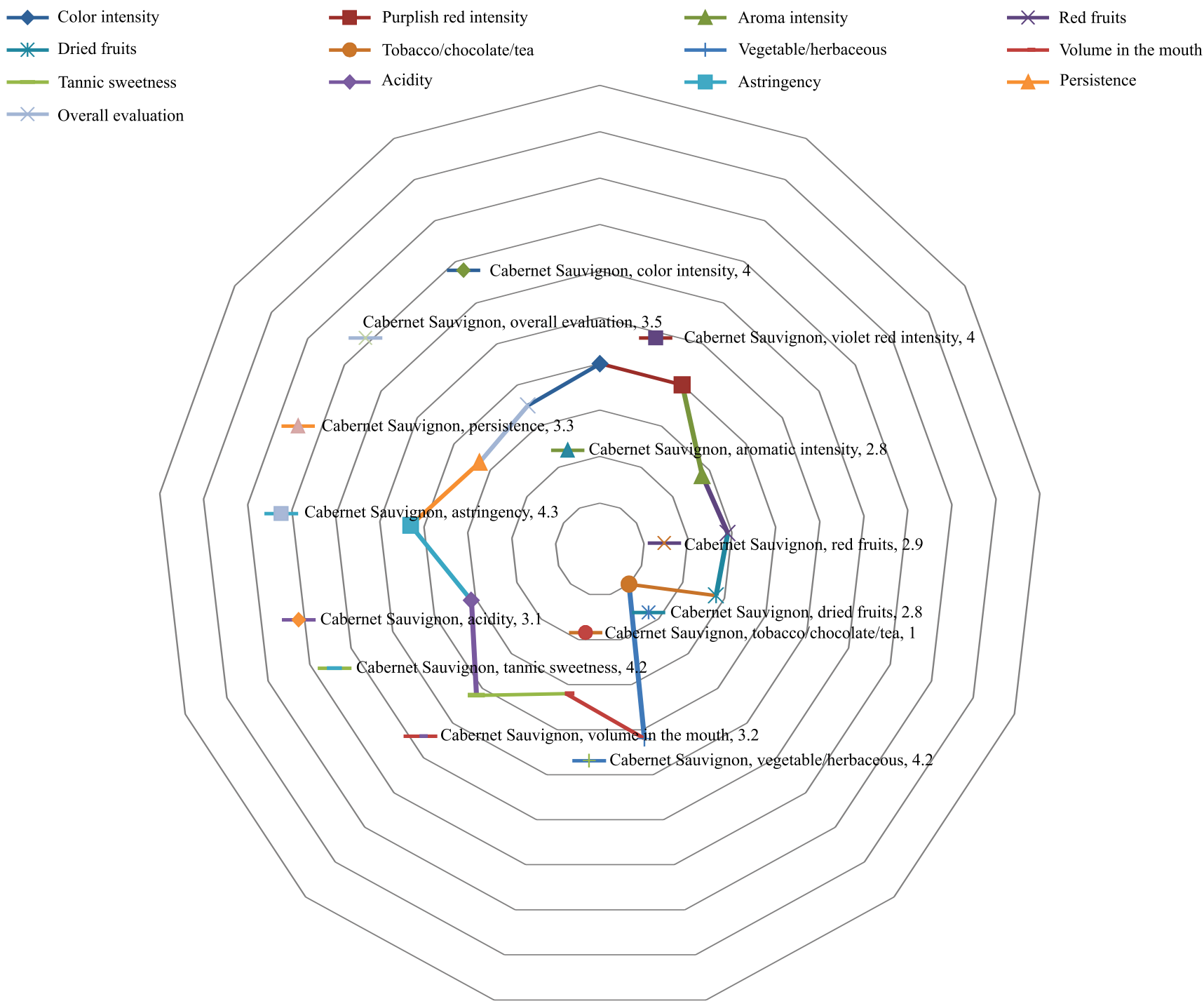

Figure 1. Sensorial analysis of 'Cabernet Sauvignon' wines made with grapes produced in the region of Bagé, RS, Brazil, in the 2008 harvest. 


\section{Conclusions}

1. 'Cabernet Sauvignon' wines produced with grapes from the region of Bagé, in the state of Rio Grande do Sul, Brazil, differ between the studied crop seasons.

2. Density, alcoholic content, total acidity, $\mathrm{pH}$, reducing sugars, OD 420, 520 and 620 , color intensity, total anthocyanins, total polyphenols, sodium, calcium, magnesium, manganese, copper, iron, rubidium, phosphorus, methanol, propanol, 2-methyl-1-propanol, 2,3 - methyl-1-butanol, and the sum of alcohols, show variations over the 2004, 2008, and 2009 crop seasons.

3. 'Cabernet Sauvignon' has potential to be produced in Bagé, and to help it to become a wine producing region in Brazil.

\section{Acknowledgments}

To Conselho Nacional de Desenvolvimento Científico e Tecnológico (CNPq) and to Coordenação de Aperfeiçoamento de Pessoal de Nível Superior (Capes), for financial support; and to $\mathrm{CNPq}$, for the research productivity grant.

\section{References}

AMERINE, M.A.; OUGH, C.S. Análisis de vinos y mostos. Zaragoza: Acribia, 1976. 158p.

ANALYTICAL methods for atomic absorption spectrophotometry. Norwalk: Perkin-Elmer, 1976. 432p.

BAIL, S.; STUEBIGER, G.; KRIST, S.; UNTERWEGER, H.; BUCHBAUER, G. Characterisation of various grape seed oils by volatile compounds, triacylglycerol composition, total phenols and antioxidant capacity. FoodChemistry, v.108, p.1122-1132, 2008. DOI: 10.1016/j.foodchem.2007.11.063.

BERTAGNOLLI, S.M.M.; ROSSATO, S.B.; SILVA, L.S.; CERVO, T.; SAUTTER, C.K.; HECKTHEUER, L.H.; PENNA, N.G. Influência da maceração carbônica e da irradiação ultravioleta nos níveis de trans-resveratrol em vinhos de uva Cabernet Sauvignon. Revista Brasileira de Ciências Farmacêuticas, v.43, p.71-77, 2007. DOI: 10.1590/S1516-93322007000100009.

BERTRAND, A. Recherches sur l'analyse des vins par chromatographie en phase gazeuse. 1975. 291p. Thèse (Doctorat) - Université de Bordeaux II, Talence.

CARVALHO, E.C.P.; CURVELO-GARCIA, A.S. Aplicação dos ácidos L-tartárico, L-láctico e DL-málico na acidificação de mostos e vinhos. Ciência e Técnica Vitivinícola, v.15, p.65-73, 2000.

CHINNICI, F.; SONNI, F.; NATALI, N.; GALASSI, S.; RIPONI, C. Colour features and pigment composition of Italian carbonic macerated red wines. Food Chemistry, v.113, p.651-657, 2009. DOI: 10.1016/j.foodchem.2008.07.055.

COSME, F.; RICARDO-DA-SILVA, J.M.; LAUREANO, O. Tannin profiles of Vitis vinifera L. cv. red grapes growing in Lisbon and from their monovarietal wines. Food Chemistry, v.112, p.197-204, 2009. DOI: 10.1016/j.foodchem.2008.05.058.

CRUZ, C.D. GENES: a software package for analysis in experimental statistics and quantitative genetics. Acta Scientiarum. Agronomy, v.35, p.271-276, 2013. DOI: 10.4025/ actasciagron.v35i3.21251.

DAUDT, C.E.; FOGAÇA, A. de O. Efeito do ácido tartárico nos valores de potássio, acidez titulável e $\mathrm{pH}$ durante a vinificação de uvas Cabernet Sauvignon. Ciência Rural, v.38, p.2345-2350, 2008. DOI: 10.1590/S0103-84782008000800039.

FALCÃO, L.D.; CHAVES, E.S.; BURIN, V.M.; FALCÃO, A.P.; GRIS, E.F.; BONIN, V.; BORDIGNON-LUIZ, M.T. Maturity of Cabernet Sauvignon berries from grapevines grown with two different training systems in a new grape growing region in Brazil. Ciencia e Investigación Agraria, v.35, p.321-332, 2008. DOI: $10.4067 / \mathrm{S} 0718-16202008000300010$

FERNÁNDEZ-ZURBANO, P.; FERREIRA, V.; PEÑA, C.; ESCUDERO, A.; CACHO, J. Effects of maceration time and pectolytic enzymes added during maceration on the phenolic composition ofmust. Food Science and Technology International, v.5, p.319, 1999. DOI: 10.1177/108201329900500404.

FISCHER, U.; ROTH, D.; CHRISTMANN, M. The impact of geographic origin, vintage and wine estate on sensory properties of Vitis vinifera cv. Riesling wines. Food Quality and Preference, v.10, p.281-288, 1999. DOI: 10.1016/S0950-3293(99)00008-7.

GONZÁLEZ-NEVES, G.; CHARAMELO, D.; BALADO, J.; BARREIRO, L.; BOCHICCHIO, R.; GATTO, G.; GIL, G.; TESSORE, A.; CARBONNEAU, A.; MOUTOUNET, M. Phenolic potential of Tannat, Cabernet-Sauvignon and Merlot grapes and their correspondence with wine composition. Analytica Chimica Acta, v.513, p.191-196, 2004. DOI: 10.1016/j.aca.2003.11.042.

JACKSON, R.S. Grape species and varieties. In: JACKSON, R.S. Wine science: principles and applications. $3^{\text {rd }}$ ed. Amsterdam; Boston: Elsevier, 2008. p.15-49. DOI: 10.1016/B978-0123736468.50005-6.

JACOBS, S.A.; JACOBS, B.; ZOCCHE, F.; ZOCCHE, R.G.S.; POTTER, G.H.; SIMOES, L.; SOUZA, V.Q.; NARDINO, M.; CARVALHO, I.R.; ROMBALDI, C.V. Microbiological characterization of grapes in the Campanha region of Rio Grande do Sul, Brazil reveals non Saccharomyces autochthonous yeasts with oenological potential. Australian Journal of Basic and Applied Sciences, v.10, p.286-294, 2016.

JAYAPRAKASHA, G.K.; SINGH, R.P.; SAKARIAH, K.K. Antioxidant activity of grape seed (Vitis vinifera) extracts on peroxidation models in vitro. Food Chemistry, v.73, p.285-290, 2001. DOI: $10.1016 / \mathrm{S} 0308-8146(00) 00298-3$.

LEEUWEN, C. van; FRIANT, P.; CHONÉ, X.; TREGOAT, O.; KOUNDOURAS, S.; DUBOURDIEU, D. Influence of climate, soil, and cultivar on terroir. American Journal of Enology and Viticulture, v.55, p.207-217, 2004. 
MANFROI, V.; MIELE, A.; RIZZON, L.A.; BARRADAS, C.I.N.; MANFROI, L. Efeito de diferentes épocas de desfolha e de colheita na composição do vinho Cabernet Sauvignon. Ciência Rural, v.27, p.139-143, 1997. DOI: 10.1590/S010384781997000100024.

PARR, W.V.; VALENTIN, D.; GREEN, J.A.; DACREMONT, C. Evaluation of French and New Zealand Sauvignon wines by experienced French wine assessors. Food Quality and Preference, v.21, 2009. DOI: 10.1016/j.foodqual.2009.08.002.

PÉREZ-LAMELA， C.; GARCÍA-FALCÓN, M.S.; SIMALGÁNDARA, J.; ORRIOLS-FERNÁNDEZ, I. Influence of grape variety, vine system and enological treatments on the colour stability of young red wines. Food Chemistry, v.101, p.601-606, 2007. DOI: 10.1016/j.foodchem.2006.02.020.

PÖTTER, G.H.; DAUDT, C.E.; BRACKAMNN, A.; LEITE, T.T.; PENNA, N.G. Desfolha parcial em videiras e seus efeitos em uvas e vinhos Cabernet Sauvignon da região da Campanha do Rio Grande do Sul, Brasil.Ciência Rural, v.40, p.2011-2016, 2010. DOI: $10.1590 / \mathrm{S} 0103-84782010000900025$.

RIBÉREAU-GAYON, P.; STONESTREET, E. Le dosage des anthocyanes dans le vin rouge. Bulletin de la Societé Chimique de France, v.9, p.2649-2652, 1965.

RIZZON, L.A.; MIELE, A. Avaliação da cv. Cabernet Sauvignon para elaboração de vinho tinto. Ciência e Tecnologia de Alimentos, v.22, p.192-198, 2002. DOI: 10.1590/S010120612002000200015.

RIZZON, L.A.; MIELE, A. Avaliação da cv. Merlot para elaboração de vinho tinto. Ciência e Tecnologia de Alimentos, v.23, p.156-161, 2003. DOI: 10.1590/S0101-20612003000400029.

RIZZON, L.A.; MIELE, A. Avaliação da cv. Tannat para elaboração de vinho tinto. Ciência e Tecnologia de
Alimentos, v.24, p.223-229, 2004. DOI: 10.1590/S010120612004000200011.

RIZZON, L.A.; SALVADOR, M.G.B.; MIELE, A. Teores de cátions dos vinhos da Serra Gaúcha. Ciência e Tecnologia de Alimentos, v.28, p.635-641, 2008. DOI: 10.1590/S010120612008000300020 .

RIZZON, L.A.; ZANUZ, M.C.; MIELE, A. Evolução da acidez durante a vinificação de uvas tintas de três regiões vitícolas do Rio Grande do Sul. Ciência e Tecnologia de Alimentos, v.18, p.179-183, 1998. DOI: 10.1590/S0101-20611998000200007.

SANTOS, H.G. dos; JACOMINE, P.K.T.; ANJOS, L.H.C. dos; OLIVEIRA, V.A. de; LUMBRERAS, J.F.; COELHO, M.R.; ALMEIDA, J.A. de; CUNHA, T.J.F.; OLIVEIRA, J.B. de. Sistema brasileiro de classificação de solos. 3.ed. rev. e ampl. Brasília: Embrapa, 2013. 353p.

SHAPIRO, S.S.; WILK, M.B. An analysis of variance test for normality (complete samples). Biometrika, v.52, p.591-611, 1965. DOI: $10.2307 / 2333709$.

SINGLETON, V.L. Oxygen with phenols and related reactions in musts, wines, and model systems: observations and practical implications. American Journal of Enology and Viticulture, v.38, p.69-77, 1987.

TAO, Y.S.; LIU, Y.-G.; LI, H. Sensory characters of Cabernet Sauvignon dry red wine from Changli County (China). Food Chemistry, v.114, p.565-569, 2009. DOI: 10.1016/j. foodchem.2008.09.087

ZOCCHE, R.G.S.; JACOBS, S.A.; SOUZA, V.Q. de; NARDINO, M.; CARVALHO, I.R.; ROMBALDI, C.V.; FACHINELLO, J.C.; RIZZON, L.A. Characterization of 'Cabernet Sauvignon' wine made with grapes from Campanha - RS Region. African Journal of Agricultural Research, v.11, p.4262-4268, 2016. DOI: 10.5897/ AJAR2016.11076.

Received on April 19, 2016 and accepted on November 28, 2016 